\title{
A New Chara Locality in the Protected Area of the Galilee Mountains, Israel
}

\author{
S. Barinova ${ }^{1, *}$, R. Romanov ${ }^{2}$ \\ ${ }^{1}$ Institute of Evolution, University of Haifa, Israel \\ ${ }^{2}$ Central Siberian Botanical Garden of the Siberian Branch of the Russian Academy of Sciences, Novosibirsk, Russia \\ *Corresponding author: barinova@research.haifa.ac.il
}

Copyright (C) 2014 Horizon Research Publishing All rights reserved.

\begin{abstract}
A new locality of Chara is described from the Nevoria pool, Upper Galilee region of Israel. The associated algal diversity is revealed, and ecological assessment aquatic environment is obtained with bio-indication methods. Algal community includes ten species two of which are charophytes Chara gymnophylla A.Braun and Spirogyra sp. The charophytes are found in mass growths in the studied pool. Bio-indication and chemical variables characterize the pool environment as eutrophic, low- to middle organically polluted, belonging to water quality Class II-III. The water is fresh, temperate, low alkaline, and well saturated with oxygen. Seasonality of algal community and water quality show a higher organic pollution in March caused by recreation impact at the end of the rainy season. The water is appreciably clearer in November at the end of the dry season, accompanied with a decrease of algal diversity. We recommend the Nevoria pool as reference site for monitoring of natural aquatic object in the Upper Galilee Mountains, for which Chara gymnophylla can be used as a climatic indicator.
\end{abstract}

Keywords Chara, ecology, bio-indication, pool, Upper Galilee Mountains, Israel

\section{Introduction}

The Chara species (Charophyta, Charales) as macroscopic autotrophic algae may be very important components of vegetation in several types of water bodies and may be used as a bio-indicator of ecosystem state, water quality, and ecosystem recovery and reservoir management efficiency. Diversity of this group in the Eastern Mediterranean is studied in initial stage. The Chara species prefer alkaline water environment which forms on the carbonates that are very distributed in studied region. This environment gives us more chance to find new, unstudied aquatic objects in which can be identified charophyte algae. The most important localities can be found in the mountain areas because altitude play the major role in historical species diversity forming process [1] especially it can be interesting in the Upper Jordan River basin, which placed in two different slopes of the Jordan Rift Valley [2,3].

Israel is partly situated in the eastern part of the Mediterranean region and partly within African-Eurasian Dry Zone [4]. Its territory contains several regions with diverse environmental features within its relatively small area. Based on this environmental diversity, we can assume the great diversity of algae of continental water bodies of Israel and in particular charophytes. The history of the study of Israel charophytes has been recently described [5], and we continue finding of new existing localities of charophytes that hitherto not been detected. Close related regions, such as Turkey, also give us charophyte algae new localities that we studied in respect of species diversity and bio-indication of its environment $[6,7]$.

This paper is on a new locality of Chara, a rare and so far poorly studied genus of higher algae macrophytes in Israel. We assessed Chara habitat on the basis of complex study of algal diversity, indicator species and water chemistry.

\section{Materials and Methods}

\subsection{Sampling and Laboratory Studies}

Material for this study comes from six living and six fixed algological samples, eighteen samples of macro-charophytes and three samples of water that were collected during two field trips in November 2012 and March 2013 in the Nevoria natural pool.

Algological samples were collected by scratching and scooping, placed in $15 \mathrm{ml}$ plastic tubes, and partly fixed with $3 \%$ neutral formaldehyde solution, as well as partly not fixed and transported to the laboratory in the ice box.

The Chara samples were treated with $2-3 \% \mathrm{HCl}$ to remove calcium carbonate. After washing several times 
with distilled water the material was studied with Nikon stereomicroscope with distilled water the material was air-dried on cover glasses and mounted in Naphrax ${ }^{\circledR}$. The structure elements were observed with Nikon with digital camera, DinoLight camera, and light microscopes (LM) in the Institute of Evolution, University of Haifa and the Central Siberian Botanical Garden with help of international handbooks $[8,9]$. Charophyte and microscopic algae abundance were assessed as abundance scores according 6-score scale [10].

Algae and cyanobacteria were studied with the SWIFT and OLYMPUS dissecting microscopes under magnifications $740 \mathrm{x}-1850 \mathrm{x}$ from three repetitions of each sample and were photographed with a DC (Inspector 1). The diatoms were prepared by the peroxide technique [11] modified for glass slides [12] and were placed in the Naphrax ${ }^{\circledR}$ resin from two repetitions of each sample.

Temperature was measured with a thermometer. Acidity $(\mathrm{pH})$, conductivity (EC), and TDS were measured with HANNA HI 9813-0. This meter has a full-spectrum $\mathrm{pH}$ measurement range. The Electrical conductivity range goes to $4.00 \mathrm{mS} \mathrm{cm}-1$. The TDS ranged from 0 to $1999 \mathrm{mg} \mathrm{l}-1$. Measurements were made by adding the probe into the water till the reading was stabilized. The concentration of N-NO3 was measured with HANNA HI 93728.

Index saprobity s was calculated according to [13]. Index of aquatic ecosystem sustainable was calculated according to $[10,14]$ as $(1)$ :

$$
\text { WESI }=\text { Rank S / Rank N-NO }
$$

Where: Rank S - rank of water quality on the Sladeček's indices of saprobity; Rank $\mathrm{N}^{-\mathrm{NO}_{3}}$ - rank of water quality on the nitric-nitrogen concentration (Table 1).
If WESI is equal to or larger than 1, the photosynthetic level is positively correlated with the level of nitrate concentration. If the WESI is less than 1, the photosynthesis is suppressed presumably according to toxic disturbance [10].

\subsection{Description of the Study Site}

The Nevoria natural pool is placed in the upper part of the Upper Galilee Mountains (Figure 1) on altitude about $690 \mathrm{~m}$ above sea level with coordinates $33^{\circ} 00^{\prime} 036 \mathrm{~N}$, $35^{\circ} 30^{\prime} 567 \mathrm{E}$ on the western slope of the rift valley near the Dalton settlement. It is small, about 6-15 $\mathrm{m}$ in diameter and up to one $m$ deep (Figure 2), filled by natural rainy waters during winter from the small stream Ein Nevoria that is right tributary of the Dalton stream, which followed to the Hatsor stream, the right tributary of the Upper Jordan River in the Northern part of Israel. While the Dalton and Hatsor streams (in the upper part) are winter streams only, the Nevoria pool is permanent. Pool is located on a forested north faced hillside of the Galilean Mountains with Pinus halepensis near the First Synagogue protected historical site, and used for recreation, year-round, but mostly in summer. Climatic condition of the Nevoria basin area is the most high and humidly in the Upper Galilee Mountains with mean annual rainfall about $800 \mathrm{~mm}$. Annual mean solar radiations in the pool area is rather high, about 182-189 kg-calories $\mathrm{cm}^{2}$ year ${ }^{-1}$ [15], like in the Judean Mountain and even in the upper Negev Desert. Therefore environment is very favorable for the development of photosynthetic plants, like Pinus halepensis in the forest, as well as Nymphaea in the studied Nevoria pool [16], and charophyte algae which are truly photosynthetic organisms.

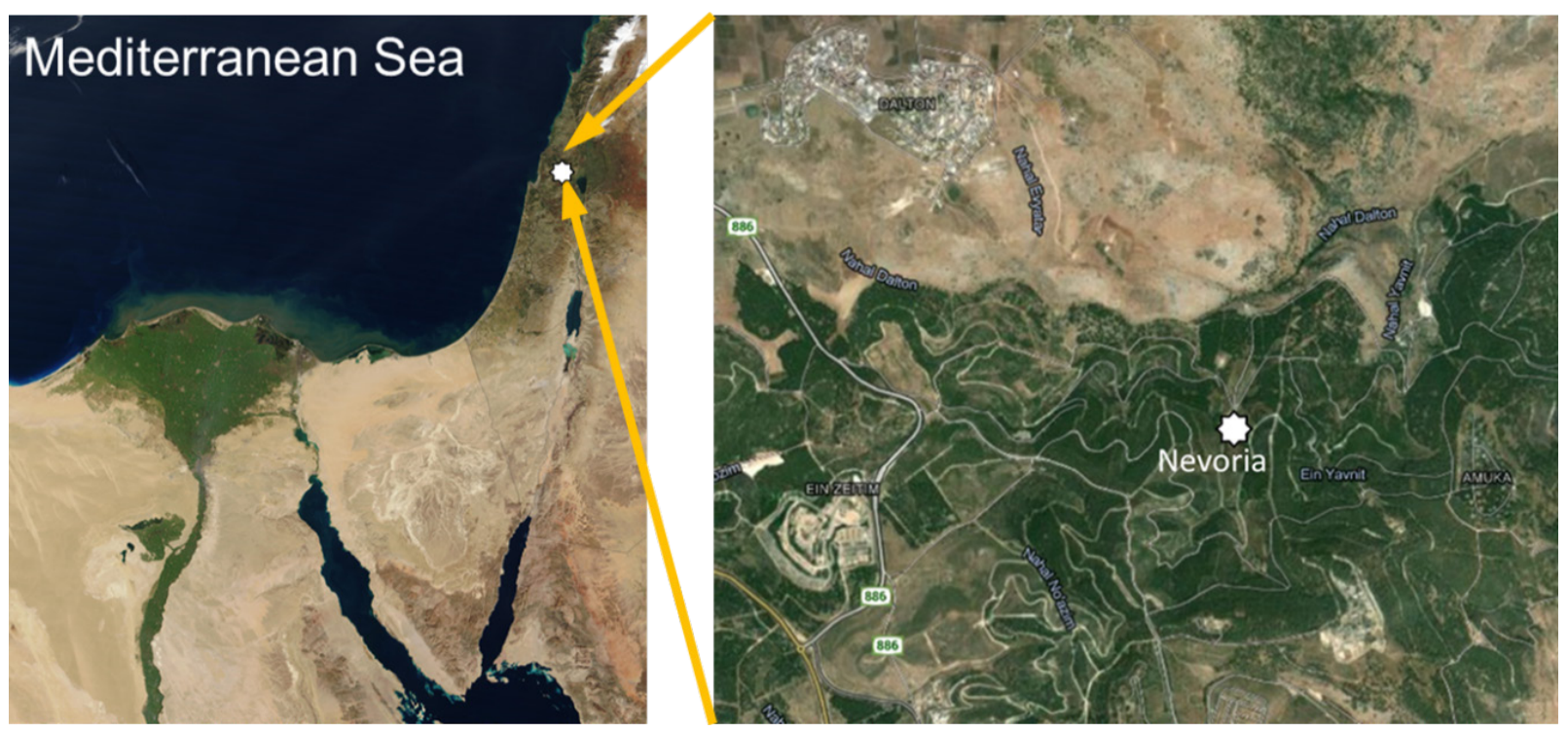

Figure 1. The Nevoria pool locality in the Upper Galilee Mountains, Israel. 


\section{Results and Discussion}

\subsection{Chemical Composition of the Pool Water}

Chemical variables were measured in two seasons: at the end of summer and at the end of winter. Table 1 show that environment variables are fluctuated in small range and reflected fresh, low alkaline, low to temperate temperature, and low polluted waters $[10,14]$ which saturated by oxygen rather enough. Index of saprobity $\mathrm{S}$ is fluctuated between 1.45 in summer and 1.60 in winter, reflect Class II to III change during the rainy period.

Table 1. Chemical and biological variables of the Nevoria pool in 2012-2013

\begin{tabular}{|c|c|c|}
\hline Variables & $\begin{array}{c}\text { November } \\
2012, \\
\text { summer }\end{array}$ & $\begin{array}{c}\text { March } \\
\text { 2013, } \\
\text { winter }\end{array}$ \\
\hline Conductivity, $\mathrm{mS} \mathrm{cm}^{-1}$ & 0.43 & 0.70 \\
\hline $\mathrm{N}-\mathrm{NO}_{3}, \mathrm{mg} \mathrm{l}^{-1}$ & 0.1 & 1.2 \\
\hline $\mathrm{pH}$ & 7.4 & 6.9 \\
\hline Total Dissolved Solids (TDS), $\mathrm{mg} \mathrm{l}^{-1}$ & 307 & 499 \\
\hline Temperature & 16.5 & 15.7 \\
\hline $\mathrm{O}_{2} \mathrm{mg} \mathrm{l}^{-1}$ & n.a. & 5.3 \\
\hline $\mathrm{O}_{2} \%$ & n.a. & 61.8 \\
\hline Index saprobity $\mathrm{S}$ & 1.45 & 1.60 \\
\hline WESI & 1.50 & 0.80 \\
\hline No. of Species & 9 & 10 \\
\hline
\end{tabular}

\subsection{Diversity and Ecology of Algae}

We revealed ten species of algae (Table 2) diversity of which is rather constant during the seasons. Studied pool surface was covered by macrophyte alga Chara gymnophylla (Figure 3), which was more abundant in winter. Structural elements and thallus habitat show (Figures 3 and 4), that our samples are in the typical diagnosis frames. It is also widely distributed species in the Mediterranean countries and some climatic similar dry regions [17] (algaebase.org). Species is simply separated from the other members of the genus Chara as we revealed by AFLP analysis [18]. The sterile Spirogyra sp. was dominant in pool especially during rainy period.

Massive Chara growth is correlated with organic enrichments of the water during rainy period that can give large nutrient base for charophytes development. Charophyte species Chara gymnophylla has wide distribution in Israel [5] over Mediterranean climatic zone [19] but in the Upper Galilee Mountains it is only one water body which it is inhabited. Other identified species in the pool were mostly diatoms that attach macrophytes, filamentous algae and stones in the pool.

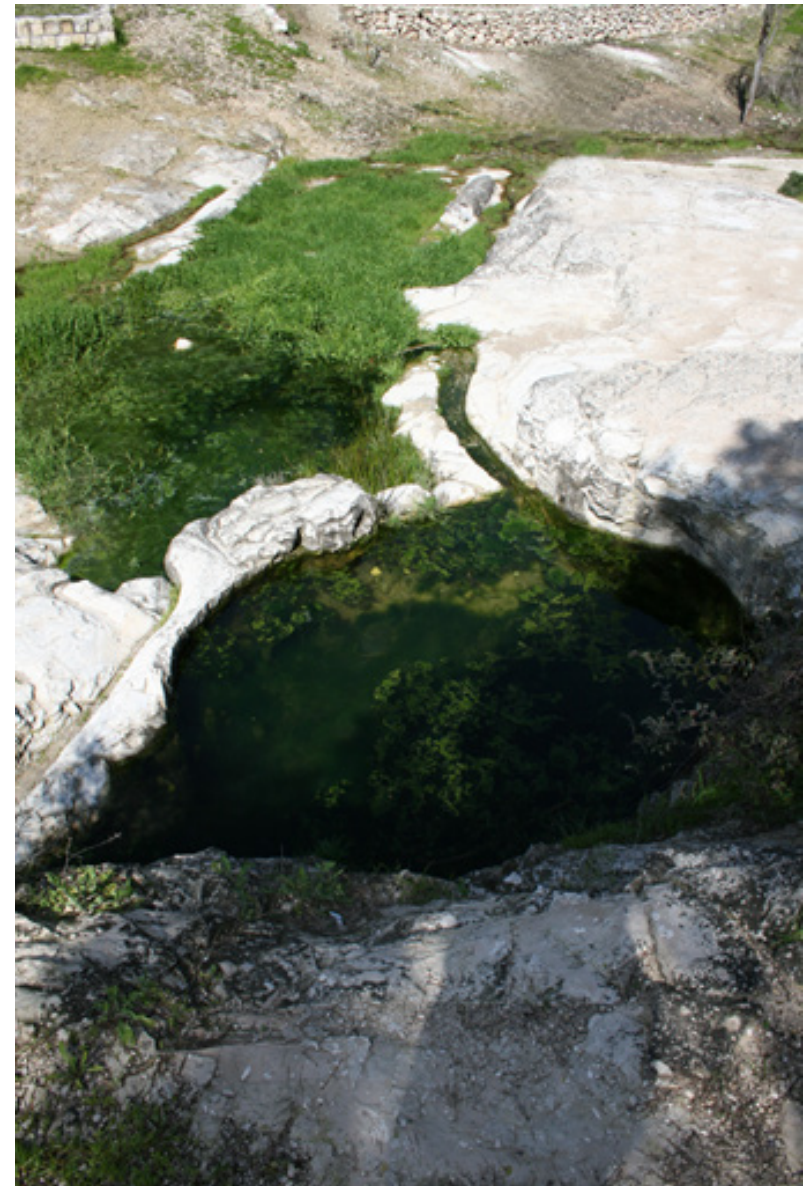

Figure 2. The Nevoria pool in March 2013 (winter).

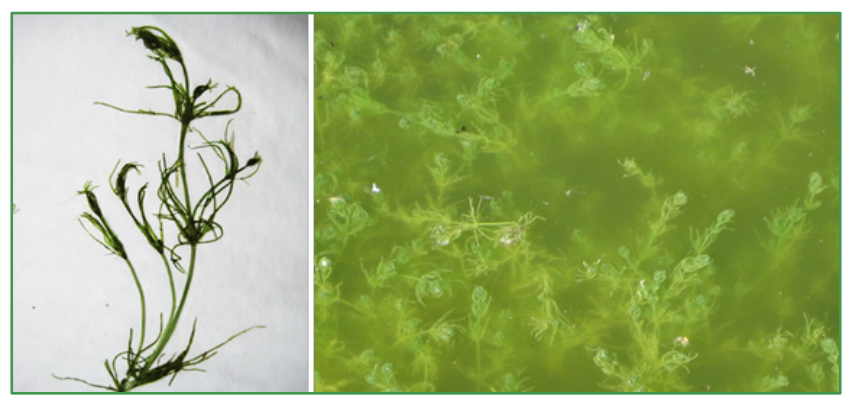

Figure 3. Chara gymnophylla: 1 - view of thallus, 2 - massive growth in the Nevoria pool

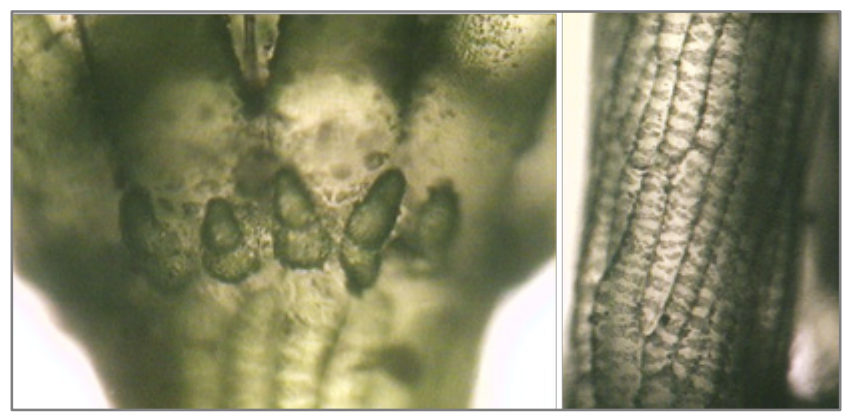

Figure 4. Chara gymnophylla: 1 - axis with stipulodes and base of whorl, 2 - axis with axial cortex 


\subsection{Bio-indication of the Studied Pool Environment}

We use bio-indication methods in purpose to characterize of the pool water quality and ecosystem sustainable. As can be seen in Table 2, the water quality defined by bio-indication is the same that show by water chemistry (Table 1). In addition we can characterize pool as eutrophic with prevailing of organisms with autotrophic type of nutrition, which are mostly attached of substrate.

We use Table 2 with Index saprobity $\mathrm{S}$ value that we calculated on the base of species abundance scores and species-specific index s (after [20] model) and nitrate concentration data (Table 1) for ecosystem state index WESI calculation. Thus, winter WESI is 0.80 , while summer WESI is 1.50 . Can be seen that ecosystem was in good condition during summer than in winter rainy season when was impacted by the organic enrichments come from the catchment area as a result of recreation. This situation is similar to that of the Upper Jordan River previously examined by us [3] where the pollution coming from the catchment area pollute the water more in winter than in summer.

Table 2. Algal diversity with abundance scores and species ecological preferences (according to [10,21]) in the Nevoria pool in 2012-2013

\begin{tabular}{|c|c|c|c|c|c|c|c|c|c|c|c|c|c|}
\hline Taxa & 2012 & 2013 & $\mathrm{Hab}$ & $\mathrm{T}$ & Reo & $\mathrm{pH}$ & $\mathrm{pH}$ range & Sal & $\mathrm{D}$ & Sap & $\mathrm{S}$ & Aut-Het & Tro \\
\hline \multicolumn{14}{|l|}{ Charophyta } \\
\hline Chara gymnophylla A.Braun & $5-6$ & 6 & B & - & - & - & - & - & - & o & 1.2 & - & - \\
\hline Spirogyra sp. ster. & 6 & 6 & B & - & - & - & - & - & - & - & 1.0 & - & - \\
\hline \multicolumn{14}{|l|}{ Chlorophyta } \\
\hline $\begin{array}{l}\text { Pseudopediastrum boryanum } \\
\text { (Turpin) E.Hegewald }\end{array}$ & - & $1-3$ & P-B & - & st-str & ind & - & $\mathrm{i}$ & - & $\mathrm{o}-\mathrm{a}$ & 2.1 & - & - \\
\hline \multicolumn{14}{|l|}{ Ochrophyta } \\
\hline $\begin{array}{l}\text { Amphora ovalis (Kützing) } \\
\text { Kützing }\end{array}$ & 1 & 2 & B & temp & st-str & alf & $6.2-9.0$ & $\mathrm{i}$ & sx & $\mathrm{a}-\mathrm{b}$ & 1.5 & ate & $\mathrm{e}$ \\
\hline $\begin{array}{l}\text { Gyrosigma acuminatum } \\
\text { (Kützing) Rabenhorst }\end{array}$ & $1-2$ & $1-2$ & B & cool & st-str & alf & - & $\mathrm{i}$ & & $0-\mathrm{x}$ & 1.9 & ate & $\mathrm{e}$ \\
\hline $\begin{array}{l}\text { Navicula viridula (Kützing) } \\
\text { Ehrenberg }\end{array}$ & $1-4$ & $1-4$ & B & - & st-str & alf & - & $\mathrm{hl}$ & es & o & 2.2 & ate & $\mathrm{e}$ \\
\hline $\begin{array}{l}\text { Cocconeis placentula } \\
\text { Ehrenberg }\end{array}$ & $2-3$ & $2-3$ & P-B & temp & st-str & alf & $5.5-9.0$ & $\mathrm{i}$ & es & o-b & 1.3 & ate & $\mathrm{e}$ \\
\hline $\begin{array}{l}\text { Caloneis bacillum (Grunow) } \\
\text { Cleve }\end{array}$ & 1 & $1-2$ & B & temp & st-str & alf & - & $\mathrm{i}$ & es & o & 1.3 & ats & me \\
\hline $\begin{array}{l}\text { Gomphonema parvulum } \\
\text { (Kützing) Kützing }\end{array}$ & $1-3$ & $2-3$ & B & temp & str & ind & $6.2-8.5$ & $\mathrm{i}$ & es & $\mathrm{x}$ & 2.3 & hne & $\mathrm{e}$ \\
\hline $\begin{array}{l}\text { Nitzschia vermicularis } \\
\text { (Kützing) Hantzsch }\end{array}$ & $1-2$ & $1-2$ & B & - & str & alf & - & $\mathrm{i}$ & & o & 2.2 & - & o-e \\
\hline
\end{tabular}

Note: Ecological types (Hab): B, benthic; P-B, planktonic-benthic. Temperature (T): cool, cool water inhabitant; temp, temperate waters inhabitant; Streaming and Oxygenation (Reo): str, streaming waters inhabitant; st-str, low streaming waters inhabitant. Acidity (pH): ind, indifferent; alf, alkaliphil. pH rank: pH amplitude in which species was found. Halobity (Sal): i, oligohalobious-indifferent; hl, oligohalobious-halophilous. Saprobity (D): es, eurysaprob; sx, saproxen. Saprobity (Sap): o, oligosaprob; o-a, oligo-alpha-mesosaprob; o-x, oligo-xenosaprob; o-b, oligo-beta-mesosaprob; a-b, alpha-beta-mesosaprob; x, xenosaprob. S: species-specific Index saprobity according Sládeček. Nitrogen uptake metabolism (Aut-Het) [21]: ats, nitrogen-autotrophic taxa, tolerating very small concentrations of organically bound nitrogen; ate, nitrogen-autotrophic taxa, tolerating elevated concentrations of organically bound nitrogen; hne, facultatively nitrogen-heterotrophic taxa, needing periodically elevated concentrations of organically bound nitrogen. Trophic state (Tro) [21]: me, meso-eutraphentic; e, eutraphentic; o-e, oligo- to eutraphentic (hypereutraphentic).

\section{Conclusion}

Charophytes study in Israel is in initial stage. The Nevoria pool as new studied locality in protected area of the First Synagogue site in the Upper Galilee Mountains can be characterize as natural, fresh, low alkaline with low organic polluted waters that inhabit by ten algal species from which the charophytes Chara gymnophylla (Characeae) and Spirogyra sp. ster. (Zygnemataceae) were rather dominated. The species Chara gymnophylla is distributed over the
Mediterranean phytogeographic realm and therefore can be used as distinct climatic indicator. It is important for the Eastern Mediterranean territory because this small area is represented by four phytogeographic realms and sharp change of altitude and climatic variables. The Nevoria pool ecosystem is slightly impacted in winter as a result of recreation. The quality of pool water assessed as fresh, low alkaline, low to temperate temperature, and low polluted waters that enough saturated by oxygen with Index of saprobity S of 1.45 and 1.60, reflect Class II-III. Therefore, 
the new Chara locality in protected area of the Upper Galilee can be monitored with using of chemical and bio-indication methods. The Nevoria pool must be protected from excessive recreation, representing more awareness of visual information for visitors.

\section{Acknowledgements}

We thank Sofa Marman for her assistance in the field trip. This work was partly funded by the Israeli Ministry of Absorption.

\section{REFERENCES}

[1] S. Barinova. The effect of altitude on distribution of freshwater algae in continental Israel, Current Topics in Plant Biology, Vol.12, 89-95, 2011a.

[2] A. Horowitz. The Jordan Rift Valley, A.A. Balkema Publishers, Lisse, Exton, PA, 2001.

[3] S. S. Barinova, E. Nevo. The Upper Jordan River algal communities are evidence of long-term climatic and anthropogenic impacts, J. Water Resource and Protection, Vol.2, 507-526, 2010

[4] A. S. Perry, R. Y. Perry. Effects in arid regions. In: Ecotoxicology and Climate, SCOPE, Published by John Wiley and Sons Ltd., 1989.

[5] R. E. Romanov, S. S. Barinova. The charophytes of Israel: historical and contemporary species richness, distribution, and ecology, Biodiv. Res. Conserv., Vol.25, 57-64, 2012

[6] S. Barinova, C.N. Solak, O. Erdoğan, R. Romanov. Algae and Zooplankton in Ecological Assessment of the Issılkl Lake, Turkey, Aquatic Biology Research, Vol.2, No.2, 23-35, 2014a.

[7] S. Barinova, R. Romanov, C.N. Solak. New record of Chara hispida (L.) Hartm. (Streptophyta: Charophyceae, Charales) from the Işıklı Lake (Turkey) and critical checklist of Turkish charophytes, Natural Resources and Conservation, Vol.2, No.3, 33-42, 2014b.
[8] D.M. John, B.A. Whitton, A.J. Brook (Eds.). The freshwater algal flora of the British Isles: an identification guide to freshwater and terrestrial algae, Cambridge University Press, Cambridge, 2011.

[9] W. Krause. Charales (Charophyceae). Süßwasserflora von Mitteleuropa, vol. 18, Gustav Fischer Verlag, Stuttgart, 1997.

[10] S.S. Barinova, L.A. Medvedeva, O.V. Anissimova. Diversity of algal indicators in environmental assessment. Pilies Studio, Tel Aviv, (Book in Russian with tables and annotation in English), 2006.

[11] E. Swift. Cleaning Diatom Frustules with Ultraviolet Radiation and Peroxide, Phycologia, Vol.6, No.2-3, 161-163, 1967.

[12] S. S. Barinova. Morphology of connective spines in diatom algae of the genus Aulacoseira Thwaites, Pa-leontological Journal, Vol.31, No.2, 239-245, 1997.

[13] V. Sládeček. Diatoms as indicators of organic pollution, Acta Hydroch. Hydrob., Vol.14, 555-566, 1986.

[14] S. Barinova. Algal diversity dynamics, ecological assessment, and monitoring in the river ecosystems of the eastern Mediterranean, Nova Science Publishers, New York, USA, $2011 b$.

[15] D. H. K. Amiram, N. Rosenan, N. Kadmon, J. Elster, M. Gilead, U. Paran (Eds.). Atlas of Israel, Ministry of Labour, Jerusalem, and Elsevier Publishing Co., Amsterdam, 1970.

[16] http://amudanan.co.il/

[17] algaebase.org

[18] G. Yehuda, S.S. Barinova, T. Krugman, T. Pavlicek, Y. Nov, E. Nevo. Microscale adaptive response of charophytes of the Negev Desert, Israel: species divergences by AFLP, Natural Resources and Conservation Vol.1, No.3, 55-64, 2013.

[19] M. Galun. The Lichens of Israel, The Israel Academy of Sciences and Humanities, Jerusalem, 1970.

[20] V. Sládeček. System of water quality from the biological point of view, Ergebnisse der Limnologie, Vol.7, 1-128, 1973.

[21] H. Van Dam, A. Martens, J. Sinkeldam. A coded checklist and ecological indicator values of freshwater diatoms from the Netherlands, Netherlands J. Aquatic Ecol., Vol.28, 117-133, 1994. 